\title{
Analysis of Paracoccidioides secreted proteins reveals fructose 1,6-bisphosphate aldolase as a plasminogen-binding protein
}

\author{
Edilânia Gomes Araújo Chaves', Simone Schneider Weber' ${ }^{1}$, Sonia Nair Báo², Luiz Augusto Pereira',
} Alexandre Melo Bailão ${ }^{1}$, Clayton Luiz Borges ${ }^{1}$ and Célia Maria de Almeida Soares ${ }^{1 *}$

\begin{abstract}
Background: Despite being important thermal dimorphic fungi causing Paracoccidioidomycosis, the pathogenic mechanisms that underlie the genus Paracoccidioides remain largely unknown. Microbial pathogens express molecules that can interact with human plasminogen, a protein from blood plasma, which presents fibrinolytic activity when activated into plasmin. Additionally, plasmin exhibits the ability of degrading extracellular matrix components, favoring the pathogen spread to deeper tissues. Previous work from our group demonstrated that Paracoccidioides presents enolase, as a protein able to bind and activate plasminogen, increasing the fibrinolytic activity of the pathogen, and the potential for adhesion and invasion of the fungus to host cells. By using proteomic analysis, we aimed to identify other proteins of Paracoccidioides with the ability of binding to plasminogen.
\end{abstract}

Results: In the present study, we employed proteomic analysis of the secretome, in order to identify plasminogen-binding proteins of Paracoccidioides, Pb01. Fifteen proteins were present in the fungal secretome, presenting the ability to bind to plasminogen. Those proteins are probable targets of the fungus interaction with the host; thus, they could contribute to the invasiveness of the fungus. For validation tests, we selected the protein fructose 1,6-bisphosphate aldolase (FBA), described in other pathogens as a plasminogen-binding protein. The protein FBA at the fungus surface and the recombinant FBA (rFBA) bound human plasminogen and promoted its conversion to plasmin, potentially increasing the fibrinolytic capacity of the fungus, as demonstrated in fibrin degradation assays. The addition of rFBA or anti-rFBA antibodies was capable of reducing the interaction between macrophages and Paracoccidioides, possibly by blocking the binding sites for FBA. These data reveal the possible participation of the FBA in the processes of cell adhesion and tissue invasion/ dissemination of Paracoccidioides.

Conclusions: These data indicate that Paracoccidioides is a pathogen that has several plasminogen-binding proteins that likely play important roles in pathogen-host interaction. In this context, FBA is a protein that might be involved somehow in the processes of invasion and spread of the fungus during infection.

Keywords: Paracoccidioides, Proteome, Secretome, Plasminogen-binding proteins, Fructose 1,6-bisphosphate aldolase

\footnotetext{
* Correspondence: cmasoares@gmail.com

'Laboratório de Biologia Molecular, Instituto de Ciências Biológicas, ICBII,

Campus II, Universidade Federal de Goiás, 74001-970 Goiânia, Goiás, Brazil

Full list of author information is available at the end of the article
} 


\section{Background}

The Paracoccidioides genus comprises a complex of pathogenic fungi, classified in at least four distinct phylogenetic lineages: S1, PS2, PS3 and Pb01-like [1-3]. These fungi are thermally dimorphic, growing at room temperatures as mycelium, which produces infectious conidia. The inhalation of conidia or mycelia propagules by the human host and their differentiation to yeast cells initiates paracoccidioidomycosis (PCM), a major health problem in South America. This human systemic mycosis is considered the tenth leading cause of chronic disease mortality among infectious and parasitic diseases, and the first among the systemic mycoses in Brazil (51.2\% of cases of deaths) [4-6].

Pathogenic microorganisms are able to penetrate and colonize host tissues by establishing complex interactions with the host molecules. Some microorganisms degrade extracellular matrix components (ECM) by using proteins that subvert proteases of the host itself [7-9]. Reports have shown that pathogens can capture plasminogen (Plg) and its activation could substantially augment the organism's potential to tissue invasion and necrosis [10-20]. In eukaryotes, $\mathrm{Plg}$ is converted to its proteolytic form, plasmin, by physiological activators such as tissue type plasminogen activator (tPA) and urokinase type (uPA) [16]. Plasmin dissociates blood clots due to its role in the degradation of fibrin polymers and promotes the dissociation of the ECM components, which is relevant for dissemination of pathogens [17-22].

There is a variety of Plg-binding proteins and activation mechanisms used by pathogens. Besides the physiological activators, molecules produced by microorganisms, can also activate plasminogen. Studies describe various Plgbinding and activating proteins involved in the degradation of host tissues, components of ECM, which favors the spread and dissemination of different pathogens [14,23-25]. In bacteria, Plg-binding and activating proteins have been characterized [12-14,24,26-37]. Those proteins can increase the bacteria fibrinolytic activity, which favors tissue degradation and rapid progression of infection $[35,38,39]$. The importance of Plg in fungi is indicated by the Plg-binding properties of human pathogens, including Candida albicans [40,41], Cryptococcus neoformans [15], Pneumocystis carinii and Aspergillus fumigatus [42,43] that depict proteins at surface, which make them able to bind Plg, and improve ther infectiveness.

The high dissemination of Paracoccidioides spp. from the site of infection to different tissues, underscores the importance of understanding the fungi virulence factors and their effects in human host. In a previous study developed by our group, we reported the recruitment of $\mathrm{Plg}$ and its activation into plasmin, by Paracoccidioides, $P b 01$, through $\mathrm{tPA}$, in a process mediated by the protein enolase [10]. The enolase of Paracoccidioides is a surface associated protein that promotes an increase in the adhesion and invasion of the fungus to host cells in in vitro models of infection $[10,44,45]$. The recombinant Paracoccidioides enolase is able to adhere to some ECM components and to the surface of macrophages, reinforcing the role of this molecule in the host-pathogen interaction [46]. These data highlight that Plg-binding proteins increase the potential for invasion and pathogenicity of Paracoccidioides through the fibrinolytic activity of plasmin. Proteins with this ability may be transported to the surface of the fungus and secreted into the external medium and promote plasmin formation, which also contributes to the pathogen dissemination [47]. In this sense, the enolase of Paracoccidioides is constitutively secreted by the yeast and mycelia phases [48], and is detected in the fungal cell wall [10].

In the present study, we employed proteomic analysis of the secretome, in order to identify Plg-binding proteins of Paracoccidioides, Pb01. Fifteen Plg-binding proteins were present in the fungal secretome. Proteins of the glycolytic pathway, such as phosphoglycerate kinase, glyceraldehyde-3-phosphate dehydrogenase and fructose 1,6-bisphosphate aldolase (FBA) were identified; the last was selected for further characterization. FBA has been described in various microorganisms as a Plg-binding protein, but its role has not been described in thermally dimorphic fungi. Here we show that Paracoccidioides binds Plg via FBA, that is found at the surface and secreted by the fungus. The protein binds human plasminogen (hPlg) and converts it into plasmin, in the presence of tPA. The interaction of the protein with hPlg, promoted increased fibrinolytic capacity of the fungus, as tested in fibrin degradation assays. The addition of recombinant FBA (rFBA) or anti-rFBA antibodies was capable of reducing the interaction between macrophages and Paracoccidioides, possibly by blocking the binding sites for FBA. These data reveal the possible participation of the FBA in the Paracoccidioides adhesion and invasion processes. The identification of novel surface/secreted proteins that can be involved in host-pathogen interaction is central to understand Paracoccidioides pathogenesis.

\section{Results and discussion}

Identification of plasminogen-binding proteins of Paracoccidioides, $\mathrm{Pb} 01$ yeast cells

In order to identify Plg-binding proteins in the secretome of Paracoccidioides, Pb01, we obtained 2-DE gels. The gels ran in parallel, were (i) stained with Coomassie brilliant blue or (ii) transferred to nitrocellulose membrane and reacted with Plg, in a Far-western blotting assay, as demonstrated in Figure 1, panel B. Image analysis were produced allowing the pairing of the proteins spots between the 2-DE gel and the membrane obtained by Far-western blotting. 


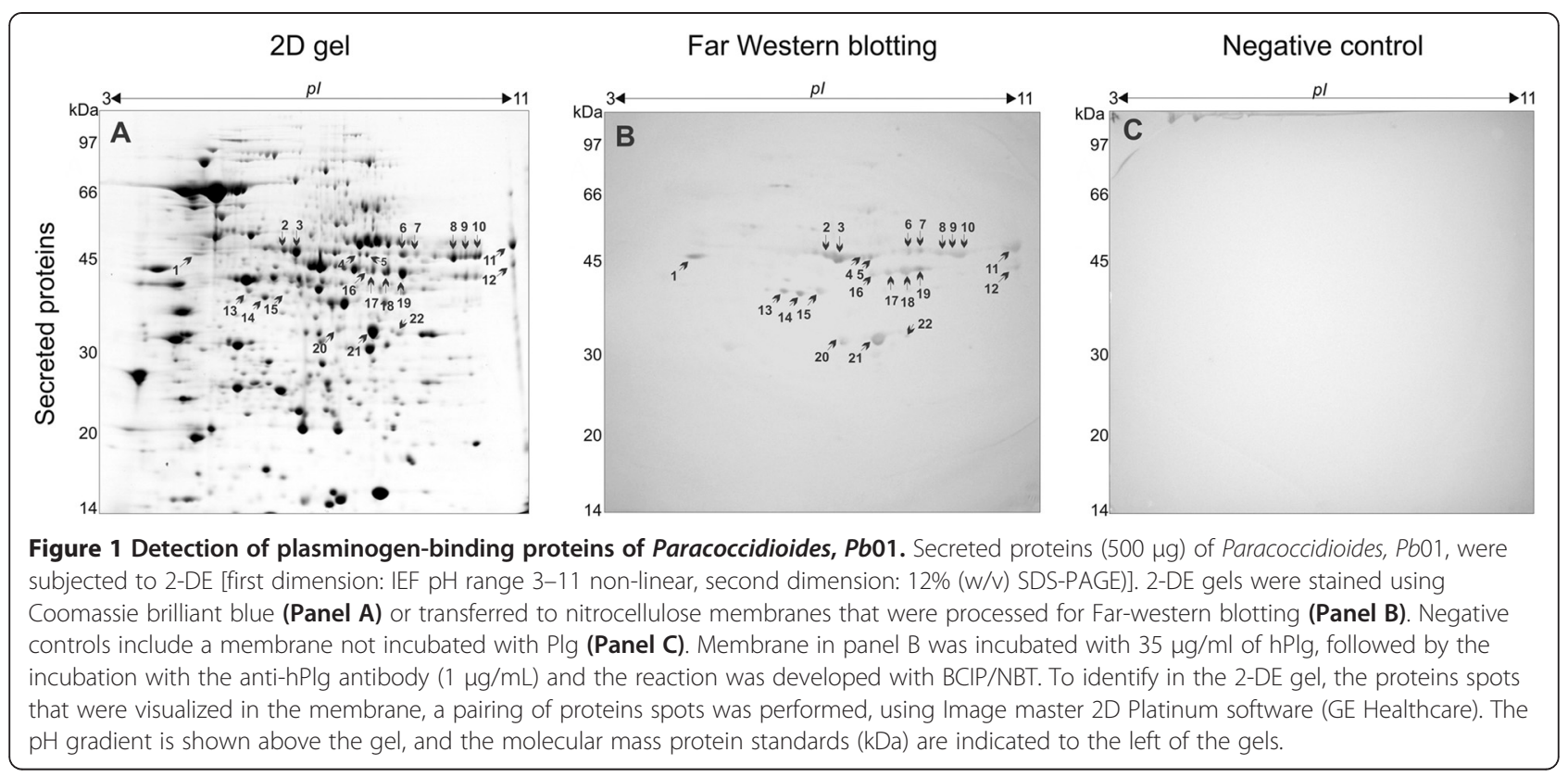

The detected spots in the membrane (Figure 1B) were compared to the Coomassie blue partners in order to find their corresponding proteins spots in the 2-DE gel (Figure 1A). Subsequently, protein spots were manually excised of the gel, and identified by mass spectrometry. It was possible to identify in the secretome of yeast cells, 22 protein spots, which bound $\mathrm{Plg}$, as depicted in Figure 1B. Figure 1, panel C, depicts the images of the negative control assay, in which the membrane was not previously incubated with $\mathrm{Plg}$, indicating no crossreactivity of the proteins with the antibody to Plg.

Spots identified as Plg-binding proteins were cut from the gel and subjected to tryptic digestion and mass spectrometry analysis. The data were used to search the Mascot, and provided the identification of 15 proteins/ isoforms. Table 1 describes the secreted proteins of Paracoccidioides, identified as Plg-binding molecules. Several enzymes were detected in this category, some of them presenting several isoforms, such as homogentisate 1,2-dioxygenase (spots 4,5), NADP-specific glutamate dehydrogenase (spots 6,7), phosphoglycerate kinase (spots 8,16) 2-methylcitrate synthase (spots 9,10,11), FBA (spots $13,14,15)$ and malate dehydrogenase (spots 20,21). Thus, the 22 protein spots identified are summed up in 15 different proteins.

While much of the proteins described in this work are not annotated in the database Psort (http://www.genscript.com/ psort/wolf_psort.html) as extracellular proteins, we found compatible data in other studies. The proteins: 2-methylcitrate synthase, FBA, glyceraldehyde 3-phosphate dehydrogenase, formamidase, acetyl-CoA acetyltransferase and phosphoglycerate kinase were detected in the secretome of Paracoccidioides, $P b 01$ yeast and mycelia [48]. Other proteins were identified in the secretome of Paracoccidioides, Pb18: FBA, glyceraldehyde 3-phosphate dehydrogenase and phosphoglycerate kinase [49]. These data corroborate the in silico analysis performed in the software Signal P and Secretome P, where we can observe that most of the proteins described here are secreted by nonclassical pathways (Table 1 ).

Some of the proteins identified in this study have also been described in other systems as Plg-binding proteins. In this way, acetyl-CoA acetyltransferase was identified in the bacteria Leptospira interrogans [50]; phosphoglycerate kinase was described in C. albicans [40], Streptococcus pneumoniae [51], as well as in C. neoformans [15]. In addition, FBA and glyceraldehyde 3-phosphate dehydrogenase were also described as Plg-binding proteins in $C$. albicans [40].

Formamidase is a highly abundant protein in Paracoccidioides, as previously described by our group [52,53]. The protein gp43 also detected in our binding assays, binds to laminin, putatively contributing to the fungus virulence and facilitating the process of infection [54,55].

The proteomic binding assays, also allowed the identification of enolase as a Plg-binding protein. The presence of glycolytic enzymes as Plg-binding proteins is reported in several pathogens, including bacteria and fungi. In Paracoccidioides, enolase is present at the yeast cells surface, where it binds and activates hPlg, presumably contributing to the fungus pathogenesis [10]. Other glycolytic enzymes, such as glyceraldehyde 3-phosphate dehydrogenase, phosphoglycerate kinase and FBA, were found here as Plg-binding proteins (Figure 1B, Table 1). Glyceraldehyde 3-phosphate dehydrogenase (GAPDH), is a molecule that binds Plg and is present on the surface and secretome of bacteria [56-58] and fungi [40]. In $C$. 
Table 1 Secreted proteins of Paracoccidioides that bind plasminogen

\begin{tabular}{|c|c|c|c|c|c|c|c|c|c|c|c|c|}
\hline Spot number ${ }^{1}$ & $\begin{array}{l}\text { General information } \\
\text { number (NCBI) })^{2}\end{array}$ & Protein description & p/theor/exp ${ }^{3}$ & $\begin{array}{l}\mathrm{MM}(\mathrm{kDa}) \\
\text { theor/exp }\end{array}$ & $\begin{array}{l}\text { PMF } \\
\text { score }^{5}\end{array}$ & $\begin{array}{l}\text { Coverage } \\
\text { sequence }(\%)^{6}\end{array}$ & $\begin{array}{l}\text { MS/MS } \\
\text { lons score }^{7}\end{array}$ & $\begin{array}{l}\text { Matched } \\
\text { peptides }^{8}\end{array}$ & $\begin{array}{l}\text { Psort } \\
\text { prediction } 9\end{array}$ & $\begin{array}{l}\text { SignalP } \\
\text { Value } \geq 0.5^{10}\end{array}$ & $\begin{array}{l}\text { SecretomeP } \\
\text { Value } \geq 0.5^{11}\end{array}$ & big-PI ${ }^{12}$ \\
\hline 1 & gi|226285916 & aminomethyl transferase & $9.67 / 4.42$ & $53.35 / 45.56$ & 121 & 37 & 84 & 4 & mito: 23.0 & NO & 0.516 & NO \\
\hline 2 & gi|226278634 & aldehyde dehydrogenase & $5.92 / 6.94$ & $54.69 / 45.97$ & 94 & 59 & 114 & 6 & cyto: 21.5 & NO & 0.562 & NO \\
\hline 3 & gi|295668479 & formamidase & $6.10 / 7.13$ & $46.14 / 45.71$ & 144 & 44 & 109 & 5 & cyto: 12.0 & NO & 0.565 & NO \\
\hline 4 & gi|295658700 & homogentisate 1,2-dioxygenase & $6.25 / 7.62$ & $50.85 / 45.51$ & 78 & 35 & - & - & cyto: 13.0 & NO & 0.601 & NO \\
\hline 5 & gi|295658700 & homogentisate 1,2-dioxygenase & $6.16 / 7.76$ & $50.86 / 45.35$ & 76 & 26 & 89 & 4 & cyto: 13.0 & NO & 0.621 & NO \\
\hline 6 & gi|295659664 & $\begin{array}{l}\text { NADP-specific glutamate } \\
\text { dehydrogenase }\end{array}$ & $7.66 / 8.48$ & $50.38 / 45.35$ & 102 & 53 & 72 & 4 & cyto: 11.0 & NO & NO & NO \\
\hline 7 & gi|295659664 & $\begin{array}{l}\text { NADP-specific glutamate } \\
\text { dehydrogenase }\end{array}$ & $7.17 / 8.75$ & $50.46 / 45.45$ & 101 & 56 & 117 & 2 & cyto: 11.0 & NO & NO & NO \\
\hline 8 & gi|295669690 & phosphoglycerate kinase & $6.48 / 9.49$ & $45.31 / 44.54$ & 83 & 61 & 151 & 5 & cyto: 25.0 & NO & NO & NO \\
\hline 9 & gi|295666179 & 2-methylcitrate synthase & $9.02 / 9.73$ & $51.51 / 45.00$ & - & - & 226 & 6 & mito: 27.0 & NO & NO & NO \\
\hline 10 & gi|295666179 & 2-methylcitrate synthase & $9.02 / 9.96$ & $51.51 / 44.92$ & 95 & 62 & 95 & 4 & mito: 27.0 & NO & NO & NO \\
\hline 11 & gi|295666179 & 2-methylcitrate synthase & $9.02 / 10.66$ & $51.58 / 47.76$ & 78 & 57 & 88 & 4 & mito: 27.0 & NO & NO & NO \\
\hline 12 & gi|295658119 & $\begin{array}{l}\text { glyceraldehyde-3-phosphate } \\
\text { dehydrogenase }\end{array}$ & $10.18 / 10.67$ & $33.92 / 43.65$ & - & - & 93 & 2 & cyto: 27.0 & NO & 0.532 & NO \\
\hline 13 & gi|295671120 & fructose 1,6-bisphosphate aldolase & $6.09 / 6.41$ & $39.72 / 41.29$ & - & & 154 & 5 & cyto: 21.0 & NO & 0.505 & NO \\
\hline 14 & gi|295671120 & $\begin{array}{l}\text { fructose 1,6-bisphosphate } \\
\text { aldolase }\end{array}$ & $6.09 / 6.60$ & $39.72 / 41.29$ & - & - & 670 & 5 & cyto: 21.0 & NO & 0.505 & NO \\
\hline 15 & gi|295671120 & fructose 1,6-bisphosphate aldolase & $6.09 / 6.88$ & $39.72 / 40.94$ & - & - & 555 & 9 & cyto: 21.0 & NO & 0.505 & NO \\
\hline 16 & gi|295669690 & phosphoglycerate kinase & $6.48 / 7.75$ & $45.31 / 42.67$ & 86 & 59 & 56 & 3 & cyto: 25.0 & NO & NO & NO \\
\hline 17 & gi|295668707 & acetyl-CoA acetyltransferase & $8.98 / 7.88$ & $46.65 / 42.67$ & & & 102 & 3 & mito: 24.5 & NO & 0.692 & NO \\
\hline 18 & gi|11496183 & immunodominant antigen Gp43 & $7.17 / 8.15$ & $45.77 / 42.42$ & 97 & 43 & 102 & 4 & extr: 24.0 & NO & 0.746 & NO \\
\hline 19 & gi|226285552 & ketol-acid reductoisomerase & $9.12 / 8.46$ & $44.86 / 42.17$ & 172 & 62 & 134 & 7 & mito: 27.0 & NO & 0.683 & NO \\
\hline 20 & gi|295658218 & malate dehydrogenase & $6.36 / 7.18$ & $34.67 / 33.98$ & 73 & 47 & 69 & 5 & cyto: 17.0 & NO & 0.674 & NO \\
\hline 21 & gi|295658218 & malate dehydrogenase & $6.36 / 7.85$ & $34.67 / 33.75$ & 129 & 41 & 344 & 9 & cyto: 17.0 & NO & 0.674 & NO \\
\hline 22 & gi|226279168 & 2,5-diketo-D-gluconic acid reductase A & $7.71 / 8.40$ & $34.78 / 33.36$ & 81 & 48 & 50 & 3 & cyto: 20.5 & 0.5 & NO & NO \\
\hline
\end{tabular}

${ }^{2} \mathrm{NCBI}$ database general information number (http://www.ncbi.nlm.nih.gov/).

Isoelectric point (theoretical/experimental).

Molecular Mass in $\mathrm{kDa}$ (theoretical/experimental);

${ }^{5}$ Mascot PMF score for fragmentation data (http://www.matrixscience.com).

${ }^{6}$ Sequence coverage percentage.

fata (http://www.matrixscience.com)

Number of identified peptides (MS/MS).

Subcellular localization prediction of proteins according Psort (http://www.genscript.com/psort/wolf_psort.html).

Secretion prediction according to Signal P 3.0 server. The number corresponds to signal peptide probability (Score ${ }^{3}$ 0.5) (http://www.cbs.dtu.dk/services/SignalP/).

Secretion prediction according to Secretome P 1.0 server; the number corresponds to neural network that exceeded a value of 0.5 (NN-score ${ }^{3} 0.50$ ) (http://www.cbs.dtu.dk/services/SecretomeP/)

${ }^{12} \mathrm{GPI}$ Modification Site Prediction of proteins according big-PI (http://mendel.imp.ac.at/gpi/gpi_server.html).

cyto: cytoplasm.

extr: extracellular.

mito: mitochondria. 
albicans, this molecule is an adhesin that participates in the process of adherence to human cells, and binds to ECM components [40,59-61]. In studies conducted by our group, GAPDH is located at the surface of Paracoccidioides, where could mediate the adhesion and internalization of the fungus to host cells, binding to ECM components [62].

Phosphoglycerate kinase is an adhesin in both, bacteria [63] and fungi $[15,40]$. On the surface of group B streptococcus, phosphoglycerate kinase binds the host actin and Plg. Binding of ECM components to bacterial proteins, including phosphoglycerate kinase, promotes the activation of specific proteins on its surface, which induces bacterial adhesion $[63,64]$. Also, proteolytic degradation of ECM by phosphoglycerate kinase - recruited plasmin activity, promotes adherence to endothelial cells and bacterial dissemination in the host tissues [36]. In $C$. neoformans, phosphoglycerate kinase localizes to the fungal cell wall, where exhibits accessible carboxylterminal lysine residues for Plg-binding [65].

FBA is cytoplasmic and also localized at the surface of several bacteria [66,67], as well as in pathogenic fungi $[15,40]$ where it binds host molecules and depicts adhesin function, beyond its glycolytic activity. In this work, three isoforms of FBA were detected (Table 1, spots 13, 14 e 15). The FBA of Paracoccidioides, Pb01 was previously characterized in our laboratory $[68,69]$. The protein is as an antigenic molecule, reactive with sera of PCM patients, as demonstrated [68]. Studies revealed the role of FBA in cell adhesion and invasion [67]. The FBA-deficient mutant of Neisseria meningitides was not affected in its ability to grow in vitro, but depicted a significant reduction in adhesion to human brain microvascular endothelial and HEp-2 cells, suggesting participation in adhesion of meningococci to human cells [67]. In C. neoformans, analysis of the Plg-binding proteins, allowed the identification of a FBA surface protein, that serves as a Plg receptor [15]. So, due to the relevance of FBA as an adhesin and a Plg-binding protein that promotes the virulence of microorganisms, the protein was selected for further investigation in Paracoccidioides.

\section{Confirmatory assays of FBA as a plasminogen-binding protein}

We selected FBA for further analysis, since the protein is a Plg-binding protein in several pathogens, as previously described $[15,40,70]$. To verify if the FBA of Paracoccidioides also has this ability, a recombinant protein was obtained by cloning the cDNA (GenBank Accession Number AY233454) into the expression vector pGEX-4 T-3 (GE Healthcare) as described in Material and Methods. The fusion protein was obtained in $E$. coli. As observed in Figure 2A, the recombinant protein was purified (lane 3 ) and cleaved from the fusion

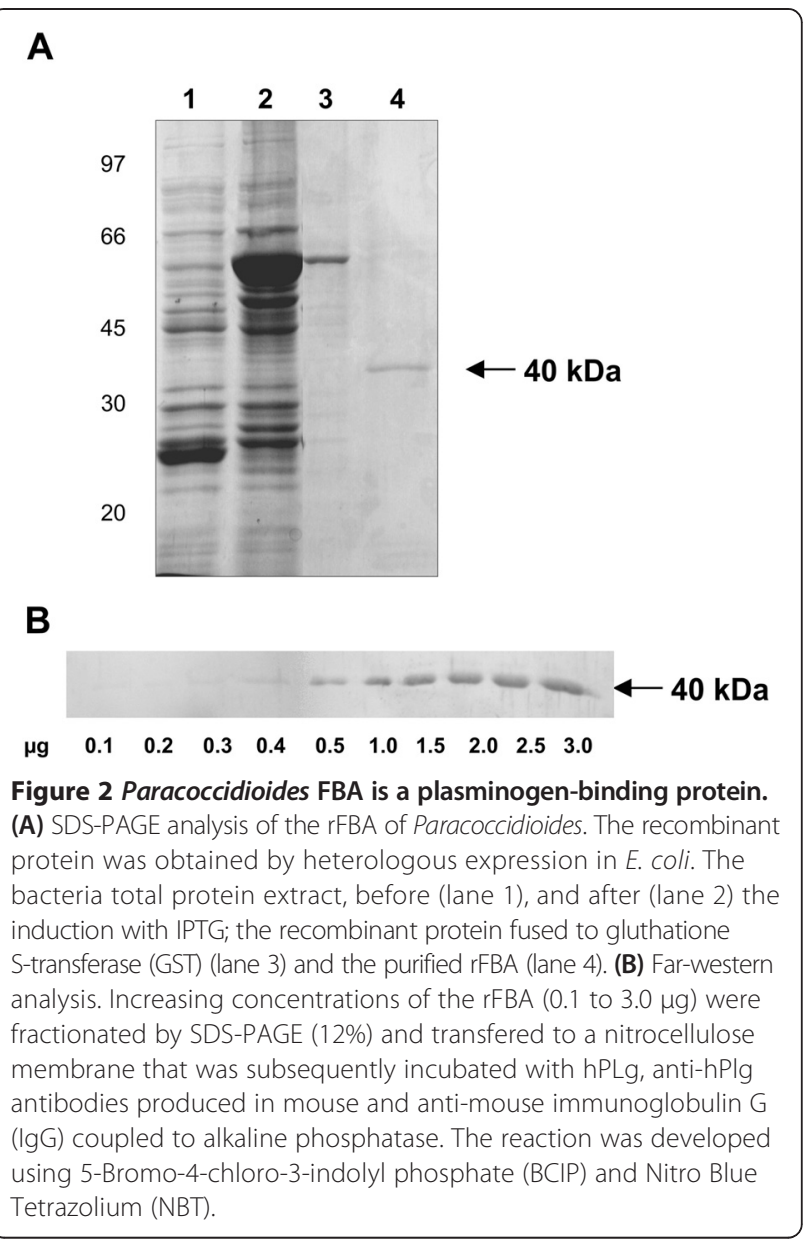

with GST by the addition of thrombin, rendering a 40-kDa protein (lane 4). A Far-western blotting with increasing concentrations of rFBA was obtained, and depicted in Figure 2B. Concentrations of $0.1 \mu \mathrm{g}$ to $3 \mu \mathrm{g}$ of the recombinant protein were subjected to Far-western, demonstrating a dose-dependent binding of the protein with Plg, showing that, in fact, the FBA of Paracoccidioides binds to the Plg.

\section{Detection of FBA at the Paracoccidioides surface}

In order to determine the localization of the FBA in Paracoccidioides, Pb01, we performed a western blotting with cellular fractions of Paracoccidioides and polyclonal antibodies raised in mice to the recombinant protein. As shown in Figure 3A, the FBA is present in the cytoplasm, secretome and cell wall (fractions 1 and 2). The fraction 1 contains proteins associated with the cell surface by non-covalent bonds or by disulfide bridges, as described [71,72]. The fraction 2 represents cell wall proteins sensitive to treatment with alkali (ASL-CWPs), including cell wall proteins with internal repeats (PIRCWPs). Fraction 3 represents proteins with glycosylphosphatidylinositol (GPI) anchors linked to the wall 

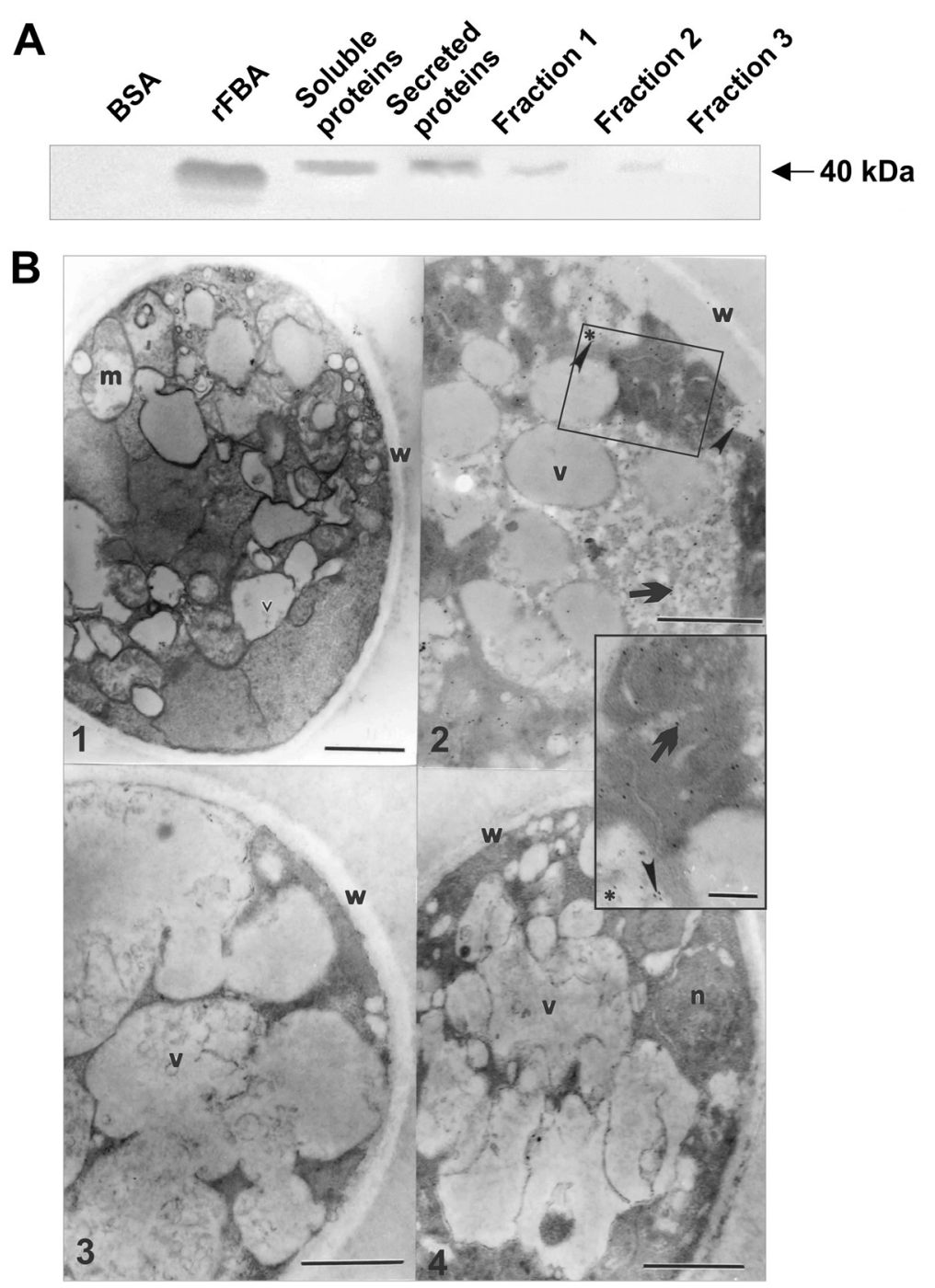

Figure 3 Detection of FBA in Paracoccidioides. (A) Western blotting analysis. Different protein samples (15 $\mu \mathrm{g}$ ) of Paracoccidioides comprehending the soluble and secreted proteins, cell wall fractions 1,2 and 3 were obtained by sequential treatments as described in Materials and Methods. For negative and positive controls, we employed $3 \mu \mathrm{g}$ of samples of bovine serum albumin (BSA) and the rFBA, respectively. The immunoblot was probed with the polyclonal antibodies directed to the rFBA. (B) Immunoelectron microscopy. Panel 1 - Transmission electron microscopy of Paracoccidioides yeast cells showing the cell wall (w), intracytoplasmic vacuoles (v), nucleus ( $n$ ) and mitochondria (m). Panel 2 - Gold particles are observed in the cytoplasm region (arrows) and vesicles in release process (arrowheads). ${ }^{*}$ corresponds to the region which has been expanded from panel 2. Panels 3 and 4 - Negative controls with anti-rabbit-igG-Au-conjugated and rabbit non immune sera, respectively. The bars indicate: $1.0 \mu \mathrm{m}$ (Panel 1), $1.0 \mu \mathrm{m}$ (Panel 2), $0.5 \mu \mathrm{m}$ (Panel 3), $1.0 \mu \mathrm{m}$ (Panel 4) and $0.5 \mu \mathrm{m}$ (Zoom panel).

(GPI-CWPs) [73,74], but rFBA was not detected in this fraction. Furthermore, the immunoelectron microscopy analysis revealed the presence of FBA in the cytoplasm, in vesicles in releasing process and at the cell surface, as depicted in Figure 3B, panel 2. The release of vesicles to the external environment is used by many pathogens to increase their invasive potential. Vesicles contain many virulence factors, including molecules that bind to and activate Plg $[27,70,75]$. The presence of FBA at the surface and vesicle of the fungus can allow the capture of hPlg and plasmin generation, forming a highly fibrinolytic layer around the fungal cell. These data suggest that FBA, can somehow influence fibrinolytic activity of yeast cells. Cell wall and secreted proteins, may participate in the process.

Paracoccidioides and rFBA bind and activate plasminogen, promoting fibrinolytic activity

We next investigated whether the capture of Plg by FBA, favors the generation of plasmin. Previous work from our group have demonstrated that yeast cells of Paracoccidioides bind to Plg [10]. As described in 
Materials and Methods the test was performed by fixation of yeast cells or the rFBA, followed by incubations with $\mathrm{hPlg}$ and tPA. In the presence of tPA, the yeast cells and the rFBA were able to generate plasmin. This ability was inhibited by the lysine analogue $(\varepsilon A C A)$, which competes for the binding sites of Plg (Figure 4A). Competition experiments were developed by adding increasing concentrations of $\varepsilon A C A$, which inhibits plasmin generation in a dose dependent manner (Figure 4B). These data suggest that yeast cells, as well as the recombinant protein bind $\mathrm{hPlg}$, converting into plasmin in the presence of tPA.

Fibrinogen is a major substrate of plasmin in vivo and for that, we examined plasmin activity in jellified matrices containing fibrinogen (Figure 4C). Fibrin degradation tests were performed in triplicate (data not shown), where yeast cells were incubated in the presence of hPlg and tPA. It was observed the formation of hydrolysis haloes within the jellified-fibrin-containing matrix (Figure $4 \mathrm{C}$, panel 3). In an attempt to block the receptor of plasminogen on the surface of the fungus, yeast cells were incubated with anti-rFBA polyclonal antibodies (Figure 4C, panel 4). A decrease in the hydrolysis halo comparing the panels 3 to 4 , can be observed. The addition of protease inhibitors resulted in no halo formation, due to inactivation of plasmin activity (Figure 4C, panels 5 and 6). Negative controls are presented in panels 1 and 2, whereas positive control is presented in panel 7 . Thus, we can conclude that FBA of Paracoccidioides may have an important role in the host tissues invasion by the fungus, besides participating in metabolic processes. Corroborating other studies on this subject, the secondary role of this protein makes it an important virulence factor. By capturing and activating Plg, FBA can promote the spread of the fungus, certainly by matrix degradation, paving the way for infection toward internal organs.

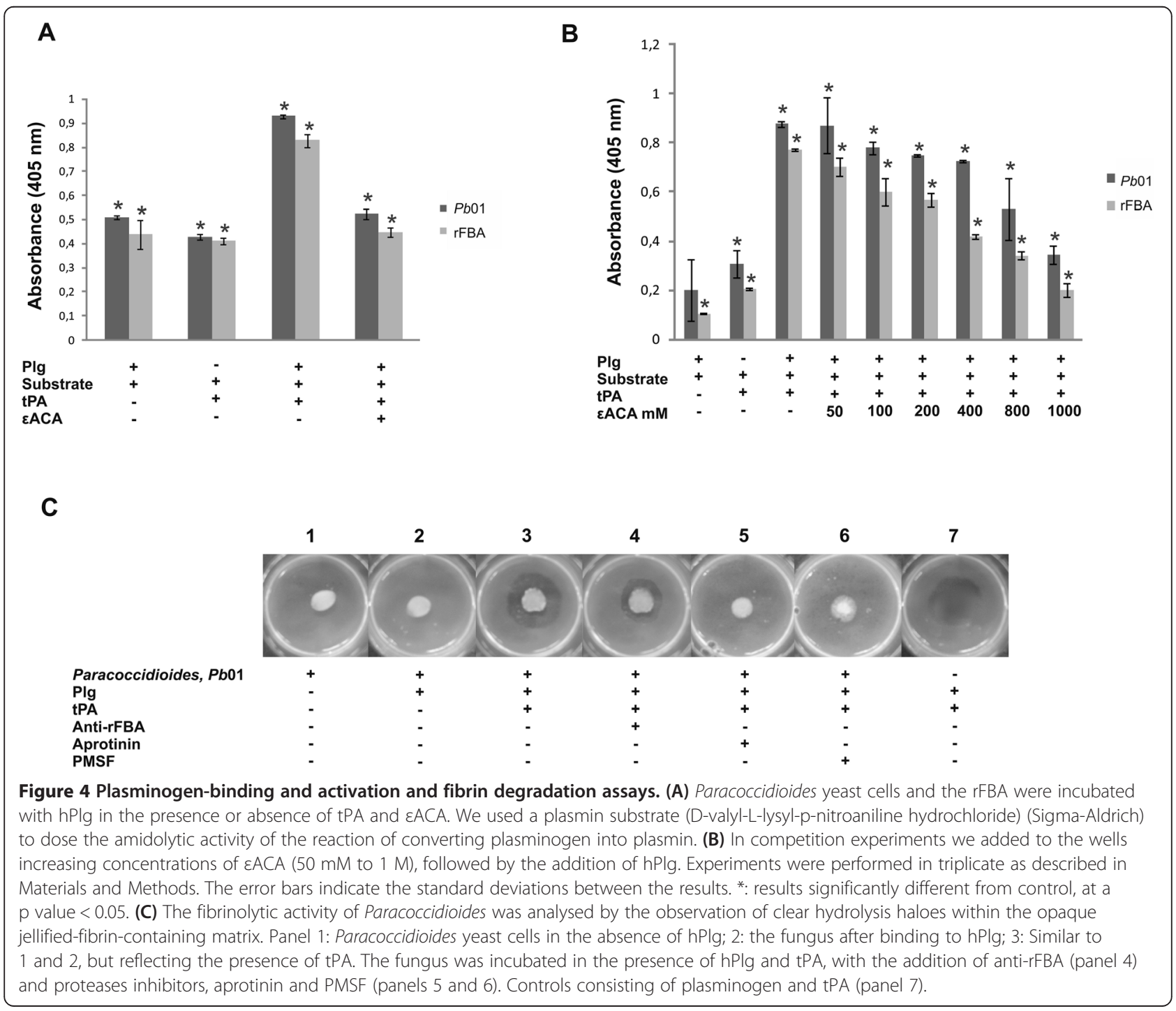




\section{rFBA influences the interaction of Paracoccidioides with macrophages}

The rFBA of Paracoccidioides behaved as an adhesin in a binding assay between 7774 and rFBA. Macrophages were able to bind/internalize the rFBA after $5 \mathrm{~h}$ incubation (Figure 5A, line 2). Control is depicted in Figure 5A, line 1 , in which no reaction was obtained in macrophages not incubated with rFBA. Positive (rFBA, Figure 5A, line 3) and negative (BSA, Figure 5A, line 4) controls, are depicted. Next, we investigated the putative role of FBA in the interaction between Paracoccidioides and macrophages. Data represent the percentage of CFUs recovered from infected macrophages, in relation to the control (Figure 5B). The results show that infection of J774 by Paracoccidioides was reduced by $79 \%$ when the macrophages were pre incubated with rFBA, and $86 \%$ when the yeast cells were pre incubated with anti-rFBA antibodies. The data strongly suggest a role for the FBA in the infective process in macrophages.

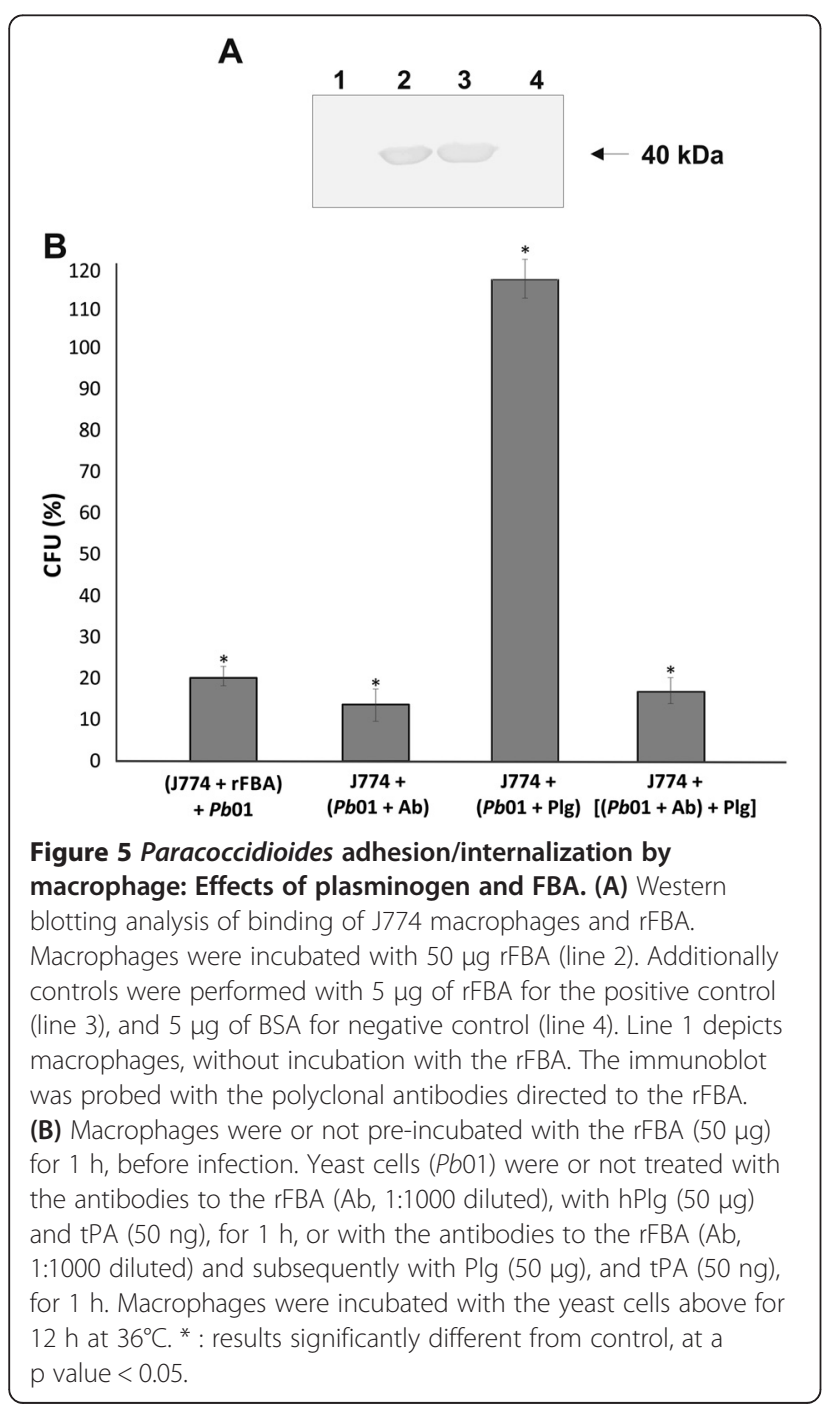

Similar experiments with other proteins such as glyceraldehyde 3-phosphate dehydrogenase and triose phosphate isomerase, that promoted reduced interaction of Paracoccidioides with pneumocytes and Vero cells, were reported [62,76]. Regarding to Plg, the pre-incubation with Paracoccidioides, in the presence of tPA, promoted increased macrophage infection (Figure 5B). The addition of the antibodies to rFBA and Plg, prompted inhibited the macrophage infection. This data is consistent with the role of FBA in activating Plg to plasmin, as previously demonstrated in Figure 4C. Our data suggest that binding of the FBA to Plg, may increase the virulence of this pathogen.

\section{Conclusions}

Many microorganisms express proteins that are able to subvert the host proteases and use them in their favor. Once activated to plasmin, Plg acquires fibrinolytic activity. Pathogens able to capture Plg can increase their potential for dissemination in the host tissues. This work identified several secreted proteins of Paracoccidioides with ability to bind to hPlg. These proteins are probable targets of the interaction of the fungus with the host, probable acting as mediators of plasmin formation, which may contribute to the invasion of the fungus in the host tissues. The FBA, was detected at the Paracoccidioides surface and secretory vesicles, in addition to the conventional cytoplasmatic localization. The protein can bind to $\mathrm{hPlg}$, converting it to plasmin in the presence of tPA. This interaction promoted increased fibrinolytic capacity of the fungus, as demonstrated in fibrin degradation assay. Moreover, we demonstrated that FBA adhered to macrophages and contribute in some way to the interaction of the fungus with these defense cells. These data suggest that FBA is a Plg-binding protein, and may be important virulence factor involved in the process of adhesion, invasion and spread of the fungus.

\section{Methods}

\section{Strains and media}

Paracoccidioides, Pb01 (ATCC MYA-826) was used in all experiments. The yeast phase was maintained in vitro by sub culturing at $36^{\circ} \mathrm{C}$ during 7 days in Fava Netto's solid medium $[1 \%(\mathrm{w} / \mathrm{v})$ peptone, $0.5 \%(\mathrm{w} / \mathrm{v})$ yeast extract, $0.3 \%(\mathrm{w} / \mathrm{v})$ proteose peptone, $0.5 \%(\mathrm{w} / \mathrm{v})$ beef extract, $0.5 \%$ $(\mathrm{w} / \mathrm{v}) \mathrm{NaCl}, 4 \%(\mathrm{w} / \mathrm{v})$ glucose, $1.2 \%(\mathrm{w} / \mathrm{v})$ agar, $\mathrm{pH} 7.2]$.

\section{Preparation of Paracoccidioides protein fractions}

To obtain the secreted proteins, the yeast cells of Paracoccidioides, Pb01 were inoculated in Fava Netto's liquid medium and cultured at $36^{\circ} \mathrm{C}$ for $24 \mathrm{~h}$ with shaking at $200 \mathrm{rpm}$, as previously described [48]. The proportion of cells used to obtain the inoculum was $2.5 \mathrm{~g}$ wet weight of yeast cells per $50 \mathrm{~mL}$ of liquid medium, or $50 \mathrm{mg} / \mathrm{mL}$. After the incubation for $24 \mathrm{~h}$, microscopic analysis was 
performed to check fungal viability, followed by cells centrifugation at $10,000 \times \mathrm{g}$, for $30 \mathrm{~min}$ at $4^{\circ} \mathrm{C}$. The supernatant was used for obtain the secreted proteins [48]. The culture supernatant was sequentially filtered through $0.45 \mathrm{~mm}$-pore and $0.22 \mathrm{~mm}$-pore membrane filters. Culture filtrates were concentrated and subsequently washed three times with ultrapure water via centrifugation $10,000 \times \mathrm{g}$ through a $10-\mathrm{kDa}$ molecular weight cut off membrane (Amicon ultra centrifugal filter, Millipore, Bedford, MA, USA). The obtained pellet, which contains the yeast cells, was used to the extraction of Paracoccidioides soluble [77] and cell wall proteins. Briefly, yeast cells were washed five times with $10 \mathrm{mM}$ Tris- $\mathrm{HCl}, \mathrm{pH} 8.5,2 \mathrm{mM} \mathrm{CaCl}_{2}$ added of the 1:1000 protease inhibitor phenyl methyl sulfonyl fluoride (PMSF) and centrifuged at $10,000 \times \mathrm{g}$ for $30 \mathrm{~min}$ at $4^{\circ} \mathrm{C}$. The cells were frozen in liquid nitrogen and disrupted by maceration. Subsequently, the precipitate was resuspended in lysis buffer $\left(20 \mathrm{mM}\right.$ Tris- $\mathrm{HCl} \mathrm{pH} \mathrm{8.8;2} \mathrm{mM} \mathrm{CaCl}_{2}$ ) added of the protease inhibitor PMSF (1:1000) and glass beads; the mixture was agitated for $1 \mathrm{~h}$. After centrifugation $10,000 \times \mathrm{g}$ for $30 \mathrm{~min}$ at $4^{\circ} \mathrm{C}$, the supernatant and pellet were used to obtain the Paracoccidioides soluble and cell wall proteins, respectively. The cell wall proteins were extracted by sequential treatments according to the type of connection that these proteins establish with other cell wall components, as previously described, with some modifications $[10,71,74,78]$. Briefly, the pellet was washed 5 times as following: with cold sterile distilled water, with $5 \%(\mathrm{w} / \mathrm{v}) \mathrm{NaCl}$, with $2 \%(\mathrm{w} / \mathrm{v}) \mathrm{NaCl}$ and with $1 \%(\mathrm{w} / \mathrm{v}) \mathrm{NaCl}$. After the washes, the pellet was treated with extraction buffer [ $50 \mathrm{mM}$ Tris $\mathrm{HCl}, \mathrm{pH} 7.8,2 \%$ (w/v) SDS, $100 \mathrm{mM}$ EDTA and $40 \mathrm{mM} \beta$-mercaptoethanol] for $10 \mathrm{~min}$ at $100^{\circ} \mathrm{C}$. The supernatant from centrifugation constitutes the first fraction (Fraction 1). The pellet resistant to extraction with SDS was washed 5 times with $0.1 \mathrm{M}$ sodium acetate $\mathrm{pH}$ 5.5. The obtained solution was centrifuged at $10,000 \times \mathrm{g}$ for $30 \mathrm{~min}$ at $4^{\circ} \mathrm{C}$ and the pellet was treated with $30 \mathrm{mM} \mathrm{NaOH}$ for $24 \mathrm{~h}$ at $4^{\circ} \mathrm{C}$, to obtain the second fraction, that after centrifugation at $10,000 \times \mathrm{g}$ for $30 \mathrm{~min}$ at $4^{\circ} \mathrm{C}$, constituted the fraction 2 . The pellet was treated with pyridine-hydrogenated fluoride (HF-pyridine) on ice for $24 \mathrm{~h}$ to give the third fraction (Fraction 3).

All the obtained protein extracts described above were concentrated and washed three times with ultrapure water via centrifugation through a $10 \mathrm{kDa}$ molecular weight cut off in ultracel regenerated membrane (Amicon ultra centrifugal filter, Millipore, Bedford, MA, USA). The protein concentrations were determined by the Bradford assay using bovine serum albumin as standard [79].

\section{Two-dimensional gel electrophoresis}

Two-dimensional fractionation (2-DE) of secreted proteins was performed, as described $[77,80]$. The 2-DE gels were obtained in duplicates, using $500 \mu \mathrm{g}$ of proteins, for each one. The samples were treated with the commercial system of purification 2D Clean-up Kit (GE Healthcare, Uppsala, Sweden) for removing interferences according to the manufacturer's instructions, before protein isoelectric focusing. Proteins samples were treated with $250 \mu \mathrm{L}$ of buffer containing $7 \mathrm{M}$ urea, $2 \mathrm{M}$ thiourea, $130 \mathrm{mM}$ 3- [(3cholamidopropyl) dimethylammonio]-1-propanesulfonate (CHAPS), $0.002 \%$ (w/v) dithiothreitol (DTT), ampholytecontaining buffer (IPG buffer, GE Healthcare), and trace amounts of bromophenol blue. Then the samples were loaded onto a $13 \mathrm{~cm}$ Immobiline ${ }^{\mathrm{TM}}$ DryStrip gel (GE Healthcare) with a $\mathrm{pH}$ range of 3-11 for separation of proteins according to their isoelectric points $(p I)$ with an electric current of $50 \mu \mathrm{A} /$ strip at $20^{\circ} \mathrm{C}$. In order to perform the first separation of secreted proteins, isoelectric focusing was conducted as following: $30 \mathrm{~V}$ for $14 \mathrm{~h}, 250 \mathrm{~V}$ for $1 \mathrm{~h}$ (step), $1 \mathrm{kV}$ for $1 \mathrm{~h}$ (step), $2 \mathrm{kV}$ for $1 \mathrm{~h}$ (step), $5 \mathrm{kV}$ for $3 \mathrm{~h}$ (gradient), $8 \mathrm{kV}$ for $8 \mathrm{~h}$ (gradient) and $8 \mathrm{kV}$ for $1 \mathrm{~h}$ (step). Strips were reduced with $18 \mathrm{mM}$ DTT (dithiothreitol) and alkylated with $135 \mathrm{mM}$ iodoacetamide in equilibration buffer [50 mM Tris- $\mathrm{HCl} \mathrm{pH}$ 8.8, $6 \mathrm{M}$ urea, 30\% $(\mathrm{v} / \mathrm{v})$ glycerol, $2 \%(\mathrm{w} / \mathrm{v})$ sodium dodecyl sulfate (SDS) and $0.002 \%(\mathrm{w} / \mathrm{v})$ bromophenol blue] during $40 \mathrm{~min}$. The second dimension was performed in $12 \%$ polyacrylamide gel electrophoresis under denaturing conditions (SDS-PAGE) in running buffer $[25 \mathrm{mM}$ Tris- $\mathrm{HCl}, 192 \mathrm{mM}$ glycine, $0.1 \%(\mathrm{w} / \mathrm{v}) \mathrm{SDS}$ ], using a vertical system (GE Healthcare) at $12^{\circ} \mathrm{C}$ during $1 \mathrm{~h}$ at $150 \mathrm{~V}$, and after at $250 \mathrm{~V}$. Two gels were stained by Commassie brilliant blue (Plus One Coomassie Tablets Phast Gel Blue R-350, GE Healthcare) according to manufacturer's instructions to visualize the proteins.

\section{Far-western}

For the Far-western experiments, the 2-DE gels were produced in duplicates. The secreted proteins, after one or two-dimensional fractionation, were transferred to nitrocellulose membranes for ligand binding with $\mathrm{Plg}$, to identify Plg-binding receptors. The results were compared to the protein pattern of the Coomassie blue stained counterpart. The membranes were incubated in blocking buffer $[0.1 \%(\mathrm{v} / \mathrm{v})$ Tween $20,5 \%(\mathrm{w} / \mathrm{v})$ skimmed powder milk, in $10 \mathrm{mM}$ PBS $(0.14 \mathrm{M} \mathrm{NaCl}, 2.7 \mathrm{mM}$ $\left.\left.\mathrm{KCl}, 10 \mathrm{mM} \mathrm{Na} \mathrm{HPO}_{4}, 1.8 \mathrm{mM} \mathrm{KH_{2 }} \mathrm{PO}_{4}, \mathrm{pH} 7.3\right)\right]$ for $1 \mathrm{~h}$ at room temperature. Subsequently, the membranes were washed three times with PBS containing $0.05 \%(\mathrm{v} / \mathrm{v})$ Tween 20 (PBS-T) and, except for the negative control, the membranes were incubated with $35 \mu \mathrm{g} / \mathrm{mL}$ of $\mathrm{hPlg}$ (Sigma-Aldrich) diluted in blocking buffer, for $1 \mathrm{~h}$ under shaking, as described [10]. Subsequently, the membranes were washed three times with PBS-T and incubated with $1 \mu \mathrm{g} / \mathrm{mL}$ anti-human plasminogen (Anti-hPlg) produced in mice (Sigma-Aldrich) diluted 1:100 in blocking buffer. 
After three washes in PBS-T, the membranes were incubated with the secondary antibody (anti-mouse IgG coupled to alkaline phosphatase) (Sigma-Aldrich) diluted 1:5000 in blocking buffer, for $1 \mathrm{~h}$. After that, the membranes were washed and the reaction was developed using 5-Bromo-4-chloro-3-indolyl phosphate (BCIP) and Nitro Blue Tetrazolium (NBT).

\section{Expression of the rFBA by Escherichia coli, purification of the recombinant protein and polyclonal antibodies production}

The cDNA that encodes FBA of Paracoccidioides, Pb01 (GenBank Accession Number AY233454) was previously obtained [69]. Oligonucleotide primers were designed: sense S (5'-GAATTCCATGGGCGTGAAAGACA-3') and antisense AT (5'-GCGGCCGCCTACAACTGGTTAGA A-3') in order to obtain the cDNA. The cDNA product obtained by RT-PCR was cloned into the expression vector pGEX-4 T-3 (GE Healthcare) and transformed into Escherichia coli XL1 blue competent cells. Bacterial cells were grown in Luria-Bertani (LB) medium supplemented with $100 \mu \mathrm{g} / \mathrm{ml}$ ampicillin under agitation at $37^{\circ} \mathrm{C}$ until the OD reaches an absorbance of 0.6 at a wavelength of $600 \mathrm{~nm}$. The reagent Isopropyl- $\beta$-D-thiogalactopyranoside (IPTG) was added to the growing culture to a final concentration of $0.1 \mathrm{mM}$. After $16 \mathrm{~h}$ incubation at $15^{\circ} \mathrm{C}$, the bacterial cells were harvested by centrifugation at $10,000 \times \mathrm{g}$ for $10 \mathrm{~min}$ and resuspended in PBS. Soluble proteins were obtained by sonication, followed by centrifugation at $10,000 \times \mathrm{g}$ during $10 \mathrm{~min}$. FBA linked to GST (glutathione-S-transferase) was affinity purified using glutathione Sepharose 4B resin (GE Healthcare). The resin was washed 10 times in PBS and the GST was cleaved by addition of thrombin $(50 \mathrm{U} / \mathrm{ml}$ ) (Sigma-Aldrich). The purity and size of the recombinant protein were assessed by SDS-PAGE followed by staining with Coomassie Blue. The rFBA was used for production of polyclonal antibodies in mice. The purified protein $(300 \mu \mathrm{g})$ was injected into mice along with Freund's adjuvant three times at intervals of 15 days. Serum containing polyclonal antibodies was collected and stored at $-20^{\circ} \mathrm{C}$.

\section{Western blotting}

For western blotting analysis, the Paracoccidioides protein samples were probed using polyclonal antibodies produced to the rFBA. Protein samples were loaded onto a $12 \%$ SDS-PAGE gel and separated by electrophoresis. The gels were run at $150 \mathrm{~V}$ for approximately $2 \mathrm{~h}$ and the proteins were transferred to nitrocellulose membranes at $30 \mathrm{~V}$ for $16 \mathrm{~h}$ in a buffer containing $25 \mathrm{mM}$ Tris- $\mathrm{HCl}(\mathrm{pH} 8.8), 190 \mathrm{mM}$ glycine and 20\% (v/v) methanol. The gels were stained with Ponceau red to verify complete protein transfer. Next, each membrane was incubated in blocking buffer [1X PBS, $1.4 \mathrm{mM}$
$\mathrm{KH}_{2} \mathrm{PO}_{4}, 8 \mathrm{mM} \mathrm{Na} \mathrm{HPO}_{4}, 140 \mathrm{mM} \mathrm{NaCl}, 2.7 \mathrm{mM} \mathrm{KCl}$ $(\mathrm{pH} 7.3), 5 \%(\mathrm{w} / \mathrm{v})$ nonfat dried milk and $0.1 \%(\mathrm{v} / \mathrm{v})$ Tween 20] for $2 \mathrm{~h}$. The membranes were washed with PBS-T, and incubated with anti-rFBA polyclonal antibodies (1:1000), followed by washing in blocking buffer three times, during 15 min each wash. The membranes were incubated with the secondary antibody anti-mouse immunoglobulin G (IgG) coupled to alkaline phosphatase (Sigma Aldrich) diluted 1:5000 in blocking buffer, for $1 \mathrm{~h}$. After that, the membranes were washed and the reaction was developed using 5-Bromo-4-chloro-3-indolyl phosphate (BCIP) and Nitro Blue Tetrazolium (NBT).

\section{Image analyses}

The comparative analysis between the images of the proteins stained with Coomassie Blue and the membranes of the Far Western assay were performed using the Image Master 2D Platinum software v7.0 (GE Healthcare) in order to identify in the 2-DE gels the protein spots that were visualized in the membranes through the pairing. The gels and membranes were aligned and the spots were compared according to their isoelectric points and molecular masses.

\section{Mass spectrometry analysis}

The spots of interest were manually excised from the 2DE gels and treated with trypsin as previously described $[48,77,80]$. The spots were removed, washed three times with ultrapure water, resuspended in $100 \mu \mathrm{L}$ of $100 \%$ acetonitrile $(\mathrm{ACN})$ and dried in a vacuum centrifuge. Subsequently, the samples were reduced with $10 \mathrm{mM}$ DDT in $25 \mathrm{mM}$ ammonium bicarbonate $\left(\mathrm{NH}_{4} \mathrm{HCO}_{3}\right)$, and alkylated with $55 \mathrm{mM}$ iodoacetamide in $25 \mathrm{mM}$ $\mathrm{NH}_{4} \mathrm{HCO}_{3}$, protected from light. The supernatant was removed and the gel pieces were washed with $100 \mu \mathrm{L}$ of a solution containing $25 \mathrm{mM}$ ammonium bicarbonate/ $50 \% \mathrm{ACN}(\mathrm{v} / \mathrm{v})$, vortexed for $5 \mathrm{~min}$, and centrifuged. Enzymatic digestion was performed by incubation at $37^{\circ} \mathrm{C}$ for $16 \mathrm{~h}$ in buffer containing trypsin $(12.5 \mathrm{ng} / \mu \mathrm{L})$ and $25 \mu \mathrm{L}$ of $25 \mathrm{mM} \mathrm{NH}_{4} \mathrm{HCO}_{3}$. The supernatant was transferred to a new tube and the gel pieces were shaken for $30 \mathrm{~min}$ in $50 \% \mathrm{ACN}(\mathrm{v} / \mathrm{v})$, and $1 \%$ trifluoroacetic acid (TFA) (v/v), followed by sonication for $5 \mathrm{~min}$, after which the supernatant was combined with the one obtained in the previous step. The dried samples were resuspended in $10 \mu \mathrm{L}$ of ultrapure water and subsequently purified using a pipette tip with a bed of chromatographic media (ZipTips ${ }^{\circ}$ C18 Pipette Tips, Millipore, Bedford, MA, USA). Two microliters of each peptide sample were deposited onto a matrix-assisted laser desorption ionization quadrupole time-of-flight mass spectrometry (MALDI-Q-TOF MS) target plate. Next, $2 \mu \mathrm{L}$ of matrix solution $(10 \mu \mathrm{g} / \mu \mathrm{L}$ a-cyano-4-hydroxyciannamic acid matrix in 50\% (v/v) ACN and 5\% (v/v) 
TFA) was added. The mass spectra were performed in the positive reflectron mode on a MALDI-Q-TOF mass spectrometer (SYNAPT, Waters Corporation, Manchester, UK). The MS/MS and PMF analysis was performed using Mascot software v. 2.4 (http://www.matrixscience.com) (Matrix Science, Boston, USA). The ion search parameters were: tryptic peptides with one missed cleavage allowed; fungi taxonomic restrictions; fixed modifications: carbamidomethylation of Cys residues; variable modifications: oxidation of methionine and a tolerance of $0.6 \mathrm{Da}$. In silico analyzes were performed to validate the results obtained in vitro. In order to predict the location of proteins we used the program Psort (http://www.genscript.com/psort/ wolf_psort.html). The software big-PI Fungal Predictor (http://mendel.imp.ac.at/gpi/fungi_server.html) was used to predict glycosylphosphatidylinositol (GPI) protein anchors. In order to predict proteins to be secreted we employed the Signal P (http://www.cbs.dtu.dk/services/ SignalP/) that predicts the classical pathway secretion and Secretome P (http://www.cbs.dtu.dk/services/SecretomeP/ ) that predicts nonclassical pathway secretion.

\section{Ultrastructure of the yeast cells and immunocytochemistry of FBA}

For the ultrastructural and immunocytochemistry studies, previously described protocols were employed $[76,81,82]$. The yeast cells were fixed in solution containing $2 \%(\mathrm{v} / \mathrm{v})$ glutaraldehyde, $2 \%(\mathrm{w} / \mathrm{v})$ paraformaldehyde, and $3 \%(\mathrm{w} / \mathrm{v})$ sucrose in $0.1 \mathrm{M}$ sodium cacodylate buffer $\mathrm{pH}$ 7.2. Ultrathin sections were stained with $3 \%(\mathrm{w} / \mathrm{v})$ uranyl acetate and lead citrate. For ultra-structural immunocytochemistry studies, the ultrathin sections were incubated for $1 \mathrm{~h}$ with the polyclonal antibodies raised against the rFBA (diluted 1:100) and for $1 \mathrm{~h}$ at room temperature with the labeled secondary antibody anti mouse IgG, Au-conjugated (10 $\mathrm{nm}$ average particle size; 1:20 dilution). The grids were stained as described above, and observed with a Jeol 1011 transmission electron microscope (Jeol, Tokyo, Japan). Controls were incubated with mouse preimmune serum (1:100 dilution).

\section{Plasminogen activation assay}

The wells of multitier plates were coated with $1 \mu \mathrm{g}$ of rFBA or fixed with $1 \times 10^{8}$ yeast cells during $1 \mathrm{~h}$. After that, the wells were incubated with $1 \mu \mathrm{g}$ of $\mathrm{hPlg}$ (Sigma-Aldrich), followed by incubation with $3 \mu \mathrm{g}$ of plasmin substrate (D-valyl-L-lysyl-p-nitroaniline hydrochloride) (Sigma-Aldrich) and $15 \mathrm{ng}$ of tPA (SigmaAldrich). Competition and control experiments were performed by blocking the generation of plasmin in the absence of tPA (Sigma-Aldrich) or in the presence of the lysine analogue $\varepsilon$-aminocaproic acid ( $\varepsilon A C A)$. The amidolytic activity of the generated plasmin was measured at $405 \mathrm{~nm}$.

\section{Fibrin matrix-gel degradation analysis}

The matrix gel contained $1.25 \%(\mathrm{w} / \mathrm{v})$ low-meltingtemperature agarose, $100 \mu \mathrm{g}$ of hPlg (Sigma- Aldrich) and $4 \mathrm{mg}$ of fibrinogen (Sigma- Aldrich) in a final volume of $2 \mathrm{~mL}$. To detect fibrinolysis activity, a total $1 \times 10^{7}$ cells of Paracoccidioides, Pb01 were incubated with $50 \mu \mathrm{g}$ of $\mathrm{hPlg}$ for $3 \mathrm{~h}$ in the presence or absence of tPA (50 ng). The yeast cells were also incubated with the serine proteinase inhibitors aprotinin $(1 \mu \mathrm{g})$, PMSF $(50 \mathrm{mM})$ and with antirFBA antibodies in a final volume of $1 \mathrm{~mL}$. Thereafter, the mixtures were washed three times with PBS and the pellets were placed in wells of a fibrin substrate matrix gel. Plasmin activity was detected by the observation of clear hydrolysis haloes within the opaque jellified fibrincontaining matrix, after incubation in a humidified chamber at $37^{\circ} \mathrm{C}$ for $12 \mathrm{~h}$.

\section{Binding assays of the rFBA to in vitro cultured macrophages}

J774 1.6 macrophages (Rio de Janeiro Cell Bank - BCRJ/ UFRJ, accession number 0273) were used for phagocytosis assays. The J774 1.6 cells were cultured in RPMI medium containing bovine fetal serum 10\% (v/v) (Vitrocell Embriolife,) containing IFN- $\gamma$ (1U per $\mathrm{mL})$ and MEM non-essential amino acid solution (Sigma Aldrich, Missouri, USA) at $36^{\circ} \mathrm{C}$ and $5 \% \mathrm{CO}_{2}$, until complete confluence. The macrophages were incubated with $50 \mu \mathrm{g} / \mathrm{mL}$ of $\mathrm{rFBA}$, at $36^{\circ} \mathrm{C}$ for $5 \mathrm{~h}$, and washed. Next, the cells were lysed by incubating with distilled water for $1 \mathrm{~h}$. The lysate was centrifuged at $1,400 \times \mathrm{g}$ for $5 \mathrm{~min}$. The proteins contained in the supernatant were submitted to SDS-PAGE and transferred to nitrocellulose membrane. The membrane was incubated blocking buffer [PBS 1X with 5\% (w/v) nonfat dried milk and $0.1 \%$ (v/v) Tween 20] for $2 \mathrm{~h}$, and then successively with antirFBA polyclonal antibodies (1:1000) and with the antimouse immunoglobulin G (IgG) coupled to alkaline phosphatase (Sigma Aldrich). The reactions were developed with BCIP-NBT.

\section{rFBA and anti rFBA-antibodies decrease Paracoccidioides macrophages interaction}

We tested the interference of the rFBA and antibodies to adhesion/infection of Paracoccidioides in macrophages. In addition, we tested the ability of Plg-treated yeast cells to adhere/infect macrophages. A total of $5 \times 10^{6}$ yeast cells, per well, were added to the macrophages, reaching a yeast:macrophages cells ratio of 5:1, followed by incubation for $12 \mathrm{~h}$ at $36^{\circ} \mathrm{C}$, in $5 \% \mathrm{CO}_{2}$, in RPMI medium containing IFN- $\gamma$ (1U per $\mathrm{mL})$. The $\mathrm{j} 774$ cells were pre incubated for $1 \mathrm{~h}$ at $36^{\circ} \mathrm{C}$ with the rFBA $(50 \mu \mathrm{g} / \mathrm{ml})$, or the yeast cells were pre- incubated with anti-rFBA antibody (1:1000) and then the infection was performed. In parallel, yeast cells were incubated with the polyclonal antibody anti-rFBA (1:1000 diluted) for $1 \mathrm{~h}$ at $36^{\circ} \mathrm{C}$, and then 
incubated with plasminogen $(50 \mu \mathrm{g})$ and tPA $(50 \mathrm{ng})$ for $1 \mathrm{~h}$ at $36^{\circ} \mathrm{C}$. After that, the yeast cells were washed three times in PBS $1 \mathrm{X}$ and incubated with the macrophages.

At the end of the infection, the adhered macrophages were washed, lysed by addition of distilled water and centrifuged. The pellet was diluted 1:10 and plated in solid BHI medium supplemented with inactivated fetal calf serum $(4 \% \mathrm{v} / \mathrm{v})$. After 7 days at $37^{\circ} \mathrm{C}$ the number of CFU's was counted.

\section{Statistical analysis}

The experiments were performed in triplicate, with samples in triplicates. Results are presented as means \pm standard deviations. Statistical comparisons were performed using Student's $t$ test and the statistical significance was accepted for $P$ value of $<0,05$.

\section{Authors' contributions}

EGAC participated in the design of the study, participated actively in all experiments and drafted the manuscript. SSW obtained protein samples, assisted in the production of 2-DE gels, cooperated in the identification and in silico analysis of proteins. SNB performed the immunoelectron microscopy assay. LAP was responsible for the production of bacteria clones expressing the rFBA and the production of polyclonal antibodies. CLB and AMB helped in the preparation of the figures of the article, in analysis and suggestions during the course of the experiments and critically revised the manuscript. CMAS designed the experiments, provided guidance during all parts of the work, and wrote the manuscript. All authors read and approved the final version of the manuscript.

\section{Acknowledgements}

The authors wish to thank the funding agencies: Coordenação de Aperfeiçoamento de Pessoal de Nível Superior (CAPES), Conselho Nacional de Desenvolvimento Científico e Tecnológico (CNPq), and Fundação de Amparo à Pesquisa do Estado de Goiás (FAPEG) by financial support.

\section{Author details}

'Laboratório de Biologia Molecular, Instituto de Ciências Biológicas, ICBII, Campus II, Universidade Federal de Goiás, 74001-970 Goiânia, Goiás, Brazil. ${ }^{2}$ Laboratório de Microscopia, Departamento de Biologia Celular, Instituto de Ciências Biológicas, Universidade de Brasília, Brasília, Distrito Federal, Brazil.

Received: 19 August 2014 Accepted: 18 February 2015

Published online: 27 February 2015

\section{References}

1. Matute DR, Sepulveda VE, Quesada LM, Goldman GH, Taylor JW, Restrepo A, et al. Microsatellite analysis of three phylogenetic species of Paracoccidioides brasiliensis. J Clin Microbiol. 2006;44(6):2153-7.

2. Carrero LL, Nino-Vega G, Teixeira MM, Carvalho MJ, Soares CMA, Pereira M, et al. New Paracoccidioides brasiliensis isolate reveals unexpected genomic variability in this human pathogen. Fungal Genet Biol. 2008;45(5):605-12.

3. Teixeira MM, Theodoro RC, de Carvalho MJ, Fernandes L, Paes HC, Hahn RC, et al. Phylogenetic analysis reveals a high level of speciation in the Paracoccidioides genus. Mol Phylogenet Evol. 2009;52(2):273-83.

4. San-Blas G, Nino-Vega G, Iturriaga T. Paracoccidioides brasiliensis and paracoccidioidomycosis: molecular approaches to morphogenesis, diagnosis, epidemiology, taxonomy and genetics. Med Mycol. 2002;40(3):225-42.

5. Shikanai-Yasuda MA, Telles Filho Fde Q, Mendes RP, Colombo AL, Moretti ML. Guidelines in paracoccidioidomycosis. Rev Soc Bras Med Trop. 2006;39(3):297-310.

6. Prado M, Silva MB, Laurenti $R$, Travassos $L R$, Taborda CP. Mortality due to systemic mycoses as a primary cause of death or in association with AIDS in Brazil: a review from 1996 to 2006. Mem Inst Oswaldo Cruz. 2009;104(3):513-21.
7. Westerlund B, Korhonen TK. Bacterial proteins binding to the mammalian extracellular matrix. Mol Microbiol. 1993;9(4):687-94.

8. Mendes-Giannini MJ, Taylor ML, Bouchara JB, Burger E, Calich VL, Escalante ED, et al. Pathogenesis II: fungal responses to host responses: interaction of host cells with fungi. Med Mycol. 2000;38 Suppl 1:113-23.

9. Furnkranz U, Siebert-Gulle K, Rosengarten R, Szostak MP. Factors influencing the cell adhesion and invasion capacity of Mycoplasma gallisepticum. Acta Vet Scand. 2013;55:63.

10. Nogueira SV, Fonseca FL, Rodrigues ML, Mundodi V, Abi-Chacra EA, Winters MS, et al. Paracoccidioides brasiliensis enolase is a surface protein that binds plasminogen and mediates interaction of yeast forms with host cells. Infect Immun. 2010;78(9):4040-50,

11. Nogueira SV, Smith AA, Qin JH, Pal U. A surface enolase participates in Borrelia burgdorferi-plasminogen interaction and contributes to pathogen survival within feeding ticks. Infect Immun. 2012;80(1):82-90.

12. Nogueira SV, Backstedt BT, Smith AA, Qin JH, Wunder Jr EA, Ko A, et al. Leptospira interrogans enolase is secreted extracellularly and interacts with plasminogen. PLoS One. 2013;8(10):e78150.

13. Agarwal V, Kuchipudi A, Fulde M, Riesbeck K, Bergmann S, Blom AM. Streptococcus pneumoniae endopeptidase $\mathrm{O}(\mathrm{PepO})$ is a multifunctional plasminogen- and fibronectin-binding protein, facilitating evasion of innate immunity and invasion of host cells. J Biol Chem. 2013;288(10):6849-63.

14. Magalhaes V, Andrade EB, Alves J, Ribeiro A, Kim KS, Lima M, et al. Group B Streptococcus hijacks the host plasminogen system to promote brain endothelial cell invasion. PLoS One. 2013;8(5):e63244.

15. Stie J, Bruni G, Fox D. Surface-associated plasminogen binding of Cryptococcus neoformans promotes extracellular matrix invasion. PLoS One. 2009;4(6):e5780.

16. Castellino FJ, Ploplis VA. Structure and function of the plasminogen/plasmin system. Thromb Haemost. 2005;93(4):647-54.

17. Bhattacharya S, Ploplis VA, Castellino FJ. Bacterial plasminogen receptors utilize host plasminogen system for effective invasion and dissemination. J Biomed Biotechnol. 2012;2012:482096.

18. Chapman HA. Plasminogen activators, integrins, and the coordinated regulation of cell adhesion and migration. Curr Opin Cell Biol. 1997;9(5):714-24.

19. Plow EF, Herren T, Redlitz A, Miles LA, Hoover-Plow JL. The cell biology of the plasminogen system. FASEB J. 1995;9(10):939-45.

20. Gonzalez A, Gomez BL, Munoz C, Aristizabal BH, Restrepo A, Hamilton AJ, et al. Involvement of extracellular matrix proteins in the course of experimental paracoccidioidomycosis. FEMS Immunol Med Microbiol. 2008;53(1):114-25.

21. Lahteenmaki K, Edelman S, Korhonen TK. Bacterial metastasis: the host plasminogen system in bacterial invasion. Trends Microbiol. 2005;13(2):79-85.

22. Geiger B, Yamada KM: Molecular architecture and function of matrix adhesions. Cold Spring Harb Perspect Biol 2011, 3(5).

23. Önder O, Humphrey PT, McOmber B, Korobova F, Francella N, Greenbaum DC, et al. OspC is potent plasminogen receptor on surface of Borrelia burgdorferi. J Biol Chem. 2012;287(20):16860-8.

24. Vieira ML, Atzingen MV, Oliveira R, Mendes RS, Domingos RF, Vasconcellos $S A$, et al. Plasminogen binding proteins and plasmin generation on the surface of Leptospira spp. the contribution to the bacteria-host interactions. J Biomed Biotechnol. 2012;2012:758513.

25. Barthel D, Singh B, Riesbeck K, Zipfel PF. Haemophilus influenzae uses the surface protein $\mathrm{E}$ to acquire human plasminogen and to evade innate immunity. J Immunol. 2012;188(1):379-85.

26. Ferreira Ede O, Teixeira FL, Cordeiro F, Araujo Lobo L, Rocha ER, Smith JC, et al. The Bfp60 surface adhesin is an extracellular matrix and plasminogen protein interacting in Bacteroides fragilis. Int J Med Microbiol. 2013;303(8):492-7.

27. Toledo A, Coleman JL, Kuhlow CJ, Crowley JT, Benach JL. The enolase of Borrelia burgdorferi is a plasminogen receptor released in outer membrane vesicles. Infect Immun. 2012;80(1):359-68.

28. Koenigs A, Hammerschmidt C, Jutras BL, Pogoryelov D, Barthel D, Skerka C, et al. BBA70 of Borrelia burgdorferi is a novel plasminogen-binding protein. J Biol Chem. 2013;288(35):25229-43.

29. Furuya $H$, lkeda R. Interaction of triosephosphate isomerase from Staphylococcus aureus with plasminogen. Microbiol Immunol. 2011;55(12):855-62. 
30. Domingos RF, Vieira ML, Romero EC, Goncales AP, de Morais ZM, Vasconcellos $\mathrm{SA}$, et al. Features of two proteins of Leptospira interrogans with potential role in host-pathogen interactions. BMC Microbiol. 2012;12:50.

31. Fernandes LG, Vieira ML, Kirchgatter K, Alves IJ, de Morais ZM, Vasconcellos $S A$, et al. OmpL1 is an extracellular matrix- and plasminogen-interacting protein of Leptospira spp. Infect Immun. 2012;80(10):3679-92.

32. Souza NM, Vieira ML, Alves IJ, de Morais ZM, Vasconcellos SA, Nascimento AL. Lsa30, a novel adhesin of Leptospira interrogans binds human plasminogen and the complement regulator C4bp. Microb Pathog. 2012:53(3-4):125-34

33. Stevenson B, Choy HA, Pinne M, Rotondi ML, Miller MC, Demoll E, et al. Leptospira interrogans endostatin-like outer membrane proteins bind host fibronectin, laminin and regulators of complement. PLoS One. 2007;2(11):e1188.

34. Bergmann S, Schoenen $\mathrm{H}$, Hammerschmidt S. The interaction between bacterial enolase and plasminogen promotes adherence of Streptococcus pneumoniae to epithelial and endothelial cells. Int J Med Microbiol. 2013;303(8):452-62.

35. Lahteenmaki K, Kuusela P, Korhonen TK. Bacterial plasminogen activators and receptors. FEMS Microbiol Rev. 2001;25(5):531-52.

36. Fulde $M$, Steinert $M$, Bergmann S. Interaction of streptococcal plasminogen binding proteins with the host fibrinolytic system. Front Cell Infect Microbiol. 2013:3:85.

37. Salazar N, Castiblanco-Valencia MM, da Silva LB, de Castro I, Monaris D, Masuda HP, et al. Staphylococcus aureus manganese transport protein C (MntC) is an extracellular matrix- and plasminogen-binding protein. PLoS One. 2014;9(11):e112730

38. Kolberg J, Aase A, Bergmann S, Herstad TK, Rodal G, Frank R, et al. Streptococcus pneumoniae enolase is important for plasminogen binding despite low abundance of enolase protein on the bacterial cell surface. Microbiology. 2006;152(Pt 5):1307-17.

39. Floden AM, Watt JA, Brissette CA. Borrelia burgdorferi enolase is a surfaceexposed plasminogen binding protein. PLoS One. 2011;6(11):e27502.

40. Crowe JD, Sievwright IK, Auld GC, Moore NR, Gow NA, Booth NA. Candida albicans binds human plasminogen: identification of eight plasminogen-binding proteins. Mol Microbiol. 2003;47(6):1637-51.

41. Poltermann S, Kunert A, von der Heide M, Eck R, Hartmann A, Zipfel PF. Gpm1 $\mathrm{p}$ is a factor $\mathrm{H}-$, FHL-1-, and plasminogen-binding surface protein of Candida albicans. J Biol Chem. 2007;282(52):37537-44

42. Fox D, Smulian AG. Plasminogen-binding activity of enolase in the opportunistic pathogen Pneumocystis carinii. Med Mycol. 2001;39(6):495-507.

43. Behnsen J, Hartmann A, Schmaler J, Gehrke A, Brakhage AA, Zipfel PF. The opportunistic human pathogenic fungus Aspergillus fumigatus evades the host complement system. Infect Immun. 2008;76(2):820-7.

44. Donofrio FC, Calil AC, Miranda ET, Almeida AM, Benard G, Soares CP, et al. Enolase from Paracoccidioides brasiliensis: isolation and identification as a fibronectin-binding protein. J Med Microbiol. 2009;58(Pt 6):706-13.

45. Marcos CM, de Fatima da Silva J, De Oliveira HC, da Silva RA M, Mendes-Giannini MJ, Fusco-Almeida AM. Surface-expressed enolase contributes to the adhesion of Paracoccidioides brasiliensis to host cells. FEMS Yeast Res. 2012;12(5):557-70.

46. Bailao AM, Nogueira SV, Rondon Caixeta Bonfim SM, De Castro KP, de Fatima da Silva J, Mendes Giannini MJ, et al. Comparative transcriptome analysis of Paracoccidioides brasiliensis during in vitro adhesion to type I collagen and fibronectin: identification of potential adhesins. Res Microbiol. 2012;163(3):182-91.

47. Ikeda R, Ichikawa T. Interaction of surface molecules on Cryptococcus neoformans with plasminogen. FEMS Yeast Res. 2014;14(3):445-50.

48. Weber SS, Parente AF, Borges CL, Parente JA, Bailao AM, Soares CMA. Analysis of the secretomes of Paracoccidioides mycelia and yeast cells. PLoS One. 2012;7(12):e52470

49. Vallejo MC, Nakayasu ES, Matsuo AL, Sobreira TJ, Longo LV, Ganiko L, et al. Vesicle and vesicle-free extracellular proteome of Paracoccidioides brasiliensis: comparative analysis with other pathogenic fungi. J Proteome Res. 2012;11(3):1676-85.

50. Vieira ML, Atzingen MV, Oliveira TR, Oliveira R, Andrade DM, Vasconcellos $\mathrm{SA}$, et al. In vitro identification of novel plasminogen-binding receptors of the pathogen Leptospira interrogans. PLoS One. 2010;5(6):e11259.

51. Fulde M, Bernardo-Garcia N, Rohde M, Nachtigall N, Frank R, Preissner KT, et al. Pneumococcal phosphoglycerate kinase interacts with plasminogen and its tissue activator. Thromb Haemost. 2014;111(3):401-16.
52. Borges CL, Pereira M, Felipe MS, de Faria FP, Gomez FJ, Deepe Jr GS, et al. The antigenic and catalytically active formamidase of Paracoccidioides brasiliensis: protein characterization, cDNA and gene cloning, heterologous expression and functional analysis of the recombinant protein. Microbes Infect. 2005;7(1):66-77.

53. Borges CL, Parente JA, Barbosa MS, Santana JM, Bao SN, de Sousa MV, et al. Detection of a homotetrameric structure and protein-protein interactions of Paracoccidioides brasiliensis formamidase lead to new functional insights. FEMS Yeast Res. 2010;10:104-13.

54. Vicentini AP, Gesztesi JL, Franco MF, de Souza W, de Moraes JZ, Travassos $L R$, et al. Binding of Paracoccidioides brasiliensis to laminin through surface glycoprotein gp43 leads to enhancement of fungal pathogenesis. Infect Immun. 1994;62(4):1465-9.

55. Popi AF, Godoy LC, Xander P, Lopes JD, Mariano M. B-1 cells facilitate Paracoccidioides brasiliensis infection in mice via IL-10 secretion. Microbes Infect. 2008;10(7):817-24.

56. Winram SB, Lottenberg R. The plasmin-binding protein Plr of group A streptococci is identified as glyceraldehyde-3-phosphate dehydrogenase. Microbiology. 1996;142(Pt 8):2311-20.

57. Egea L, Aguilera L, Gimenez R, Sorolla MA, Aguilar J, Badia J, et al. Role of secreted glyceraldehyde-3-phosphate dehydrogenase in the infection mechanism of enterohemorrhagic and enteropathogenic Escherichia coli: interaction of the extracellular enzyme with human plasminogen and fibrinogen. Int J Biochem Cell Biol. 2007;39(6):1190-203.

58. Tunio SA, Oldfield NJ, Ala'Aldeen DA, Wooldridge KG, Turner DP. The role of glyceraldehyde 3-phosphate dehydrogenase (GapA-1) in Neisseria meningitidis adherence to human cells. BMC Microbiol. 2010;10:280.

59. Gil-Navarro I, Gil ML, Casanova M, O'Connor JE, Martinez JP, Gozalbo D. The glycolytic enzyme glyceraldehyde-3-phosphate dehydrogenase of Candida albicans is a surface antigen. J Bacteriol. 1997;179(16):4992-9.

60. Gozalbo D, Gil-Navarro I, Azorin I, Renau-Piqueras J, Martinez JP, Gil ML. The cell wall-associated glyceraldehyde-3-phosphate dehydrogenase of Candida albicans is also a fibronectin and laminin binding protein. Infect Immun. 1998;66(5):2052-9.

61. Luo S, Poltermann S, Kunert A, Rupp S, Zipfel PF. Immune evasion of the human pathogenic yeast Candida albicans: Pra1 is a Factor $\mathrm{H}, \mathrm{FHL}-1$ and plasminogen binding surface protein. Mol Immunol. 2009;47(2-3):541-50.

62. Barbosa MS, Bao SN, Andreotti PF, de Faria FP, Felipe MS, dos Santos FL, et al. Glyceraldehyde-3-phosphate dehydrogenase of Paracoccidioides brasiliensis is a cell surface protein involved in fungal adhesion to extracellular matrix proteins and interaction with cells. Infect Immun. 2006;74(1):382-9.

63. Boone TJ, Tyrrell GJ. Identification of the actin and plasminogen binding regions of group B streptococcal phosphoglycerate kinase. J Biol Chem. 2012;287(34):29035-44

64. Hoffmann C, Berking A, Agerer F, Buntru A, Neske F, Chhatwal GS, et al. Caveolin limits membrane microdomain mobility and integrin-mediated uptake of fibronectin-binding pathogens. J Cell Sci. 2010;123(Pt 24):4280-91.

65. Miles LA, Dahlberg CM, Plescia J, Felez J, Kato K, Plow EF. Role of cell-surface lysines in plasminogen binding to cells: identification of alpha-enolase as a candidate plasminogen receptor. Biochemistry. 1991;30(6):1682-91.

66. de la Paz SM, Gest PM, Guerin ME, Coincon M, Pham H, Ryan G, et al. Glycolytic and non-glycolytic functions of Mycobacterium tuberculosis fructose-1,6-bisphosphate aldolase, an essential enzyme produced by replicating and non-replicating bacilli. J Biol Chem. 2011;286(46):40219-31.

67. Tunio SA, Oldfield NJ, Berry A, Ala'Aldeen DA, Wooldridge KG, Turner DP. The moonlighting protein fructose-1, 6-bisphosphate aldolase of Neisseria meningitidis: surface localization and role in host cell adhesion. Mol Microbiol. 2010;76(3):605-15.

68. da Fonseca CA, Jesuino RS, Felipe MS, Cunha DA, Brito WA, Soares CMA. Two-dimensional electrophoresis and characterization of antigens from Paracoccidioides brasiliensis. Microbes Infect. 2001;3(7):535-42.

69. Carneiro LC, de Faria FP, Felipe MS, Pereira M, Soares CMA. Paracoccidioides brasiliensis presents two different cDNAs encoding homologues of the fructose 1,6-biphosphate aldolase: protein isolation, cloning of the cDNAs and genes, structural, phylogenetic, and expression analysis. Fungal Genet Biol. 2005;42(1):51-60.

70. Figuera L, Acosta H, Gomez-Arreaza A, Davila-Vera D, Balza-Quintero A, Quinones W, et al. Plasminogen binding proteins in secreted membrane vesicles of Leishmania mexicana. Mol Biochem Parasitol. 2013;187(1):14-20. 
71. Pitarch A, Sanchez M, Nombela C, Gil C. Sequential fractionation and two-dimensional gel analysis unravels the complexity of the dimorphic fungus Candida albicans cell wall proteome. Mol Cell Proteomics. 2002;1(12):967-82.

72. Pitarch A, Nombela C, Gil C. Cell wall fractionation for yeast and fungal proteomics. Methods Mol Biol. 2008:425:217-39.

73. Kapteyn JC, Van Den Ende H, Klis FM. The contribution of cell wall proteins to the organization of the yeast cell wall. Biochim Biophys Acta. 1999;1426(2):373-83.

74. de Groot PW, de Boer AD, Cunningham J, Dekker HL, de Jong L, Hellingwerf $\mathrm{K}$, et al. Proteomic analysis of Candida albicans cell walls reveals covalently bound carbohydrate-active enzymes and adhesins. Eukaryot Cell. 2004;3(4):955-65.

75. Eddy JL, Gielda LM, Caulfield AJ, Rangel SM, Lathem WW. Production of outer membrane vesicles by the plague pathogen Yersinia pestis. PLoS One. 2014;9(9):e107002.

76. Pereira LA, Bao SN, Barbosa MS, da Silva JL, Felipe MS, de Santana JM, et al. Analysis of the Paracoccidioides brasiliensis triosephosphate isomerase suggests the potential for adhesin function. FEMS Yeast Res. 2007;7(8):1381-8

77. Parente AF, Bailao AM, Borges $C L$, Parente $J A$, Magalhaes $A D$, Ricart $C A$, et al. Proteomic analysis reveals that iron availability alters the metabolic status of the pathogenic fungus Paracoccidioides brasiliensis. PLoS One. 2011;6(7):e22810

78. da Silva CN, Barbosa MS, Maia ZA, Bao SN, Felipe MS, Santana JM, et al. Characterization of Paracoccidioides brasiliensis PbDfg5p, a cell-wall protein implicated in filamentous growth. Yeast. 2008;25(2):141-54.

79. Bradford MM. A rapid and sensitive method for the quantitation of microgram quantities of protein utilizing the principle of protein-dye binding. Anal Biochem. 1976;72:248-54.

80. Rezende TC, Borges CL, Magalhaes AD, de Sousa MV, Ricart CA, Bailao AM, et al. A quantitative view of the morphological phases of Paracoccidioides brasiliensis using proteomics. J Proteomics. 2011;75(2):572-87.

81. Castro N da S, de Castro KP, Orlandi I, Feitosa Ldos S, Silva LK R e, Vainstein $\mathrm{MH}$, et al. Characterization and functional analysis of the beta-1,3-glucanosyltransferase 3 of the human pathogenic fungus Paracoccidioides brasiliensis. FEMS Yeast Res. 2009;9(1):103-14.

82. de Sousa LP, Bailao EF, Silva MG, Castro Nda S, Bao SN, Orlandi I, et al. Characterization of the Paracoccidioides beta-1,3-glucanosyltransferase family. FEMS Yeast Res. 2012;12(6):685-702.

\section{Submit your next manuscript to BioMed Central and take full advantage of:}

- Convenient online submission

- Thorough peer review

- No space constraints or color figure charges

- Immediate publication on acceptance

- Inclusion in PubMed, CAS, Scopus and Google Scholar

- Research which is freely available for redistribution 